\title{
Study of Incubation Conditions for Erythrocytes Osmotic Fragility Testing in Dromedary Camel (Camelus dromedarius)
}

\section{LEKTIB Islah ${ }^{1}$, BARGAÂ Rita ${ }^{2}$, CHAKIR Youssef ${ }^{2}$, BELHOUARI Abdarrahmane $^{2}$, HAMMOUMI Abdarrahman ${ }^{1}$, EL KHASMI Mohammed ${ }^{2 *}$}

${ }^{1}$ Laboratory of Microbiology, Pharmacology, Biotechnology and Environment, Faculy of sciences Aïn-Chock, Hassan II University of Casablanca, P.B 5366 Maârif, Casablanca, Morocco

${ }^{2}$ Laboratory of Physiopathology and Molecular Genetic, Faculty of Sciences Ben M'Sik, Hassan II University of Casablanca, P.B 7955 Sidi Othmane, Casablanca, Morocco lektibislah@gmail.com,ha2m@hotmail.com,rita-bargaa@live.fr,y.chakir@hotmail.com, abderrahmane.belhouari@gmail.com,*elkhasmimohammed@gmail.com

\begin{abstract}
The values of the erythrocytes osmotic fragility (EOF) test are easily influenced by physiological and environmental conditions surounding during blood collection, and red blood cells (RBCs) preparation and incubation. Therefore, the aim of our study was to determine the influence of anticoagulant (EDTA and heparin), temperature, $\mathrm{pH}$, storage time, age, sex, season, hydrogen peroxide and vitamins $C$ and $E$, on EOF in dromedary camel. The results showed an increased EOF by EDTA, storage time, cold, heat, acidity and hydrogen peroxide. In addition, this EOF was influenced by age, sex, season and vitamins. As conclusion, the quality of the OF test may easily be influenced by several biological, environmental and technical factors which must be determined and mentioned in each analysis of EOF profile in camel. These factors induced damage to RBCs cell membrane and may disturb the results of other blood analyses such as measurements of various hematological and biochemical parameters in camel.
\end{abstract}

Keywords: Osmotic fragility, EDTA, Heparin, Temperature, pH, Storage time, Age, Sex, Season, Camel. Abreviations: EDTA: Ethylene Diamine Tetra acetic Acid, EOF: Erythrocyte Osmotic Fragility $\mathrm{H}_{2} \mathrm{O}_{2}$ : Hydrogen Peroxide, H\%: Percent Hemolysis, OF: Osmotic Fragility, OS: Oxidant Stress PBS: phosphate buffered saline, RBCs : Red Blood Cells, ROS : Reactive Oxygen Species.

\section{INTRODUCTION}

Hemolysis is usually recognized by free hemoglobin in the red blood cell (RBC)-suspending media. The erythrocyte osmotic fragility (EOF) test is used to determine the extent of red blood cells (RBCs) hemolysis produced by osmotic stress. This extent is dependent on cell volume, surface area, and functional integrity of cell membranes. Since it can be followed by changes in absorbance at $540 \mathrm{~nm}$, the EOF test was frequently applied to the diagnosis of hemolytic diseases and oxidant alterations leading to destruction of erythrocytes [1,2,3]. For example, road transportation to slaughterhouses associated to heat stress had been demonstrated to cause increase of hemolysis in pig [3], goat [4] and camel [5]. Nonetheless, the technical quality of this test is easily influenced by environmental changes. In fact, hemolysis has been shown to be affected by technical conditions of the assay and several factors, including age [6], sex [7], temperature, $\mathrm{pH}$ [8], season [9], transportation [10,11], inappropriate storage conditions, defects in the RBC membrane and abnormality in the blood [12]. These factors have been suggested to affect the EOF test and must be strictly standardized to obtain reproducible results. Therefore, we have undertaken a study in order to determine the osmotic fragility (OF) values of RBCs under several conditions in camel. We have assessed the effects of anticoagulant (EDTA and heparin), storage time, temperature, $\mathrm{pH}$, hydrogen peroxide, vitamins, sex, age and season on EOF in this species.

\section{Materials ANd Methods}

\subsection{Animals}

To investigate the effect of all factors studied here on OF of erythrocytes, 66 male and 6 female camels ( 3 to 10 years of age, average weight of $340.24 \pm 69.98 \mathrm{~kg}$ ) from Casablanca Municipality slaughterhouse were used as indicated in Table 1 . These camels were clinically healthy and feed deprived overnight. 
LEKTIB Islah et al.

Table1. Experimental Design

\begin{tabular}{|l|l|l|l|}
\hline $\begin{array}{l}\text { Parameters } \\
\text { tested }\end{array}$ & $\begin{array}{l}\text { Tubes used for } \\
\text { blood sampling }\end{array}$ & $\begin{array}{l}\text { Number and } \\
\text { sex of camels }\end{array}$ & $\begin{array}{l}\text { Period } \\
\text { of year }\end{array}$ \\
\hline Anticoagulant & $\begin{array}{l}\text { EDTA } \\
\text { Heparin }\end{array}$ & $\begin{array}{l}8 \text { males } \\
8 \text { males }\end{array}$ & $\begin{array}{l}\text { October } \\
\text { October }\end{array}$ \\
\hline $\begin{array}{l}\text { Storage time, } \\
\text { Temperature, pH }\end{array}$ & Heparin & 7 males & October \\
\hline $\begin{array}{l}\text { Hydrogen peroxide, } \\
\text { Vitamins C and E }\end{array}$ & Heparin & 7 males & November \\
\hline Sex & Heparin & 6 males \\
6 females & $\begin{array}{l}\text { March - April } \\
\text { March - April }\end{array}$ \\
\hline Age & Heparin & 7 old males & $\begin{array}{l}\text { December-January } \\
\text { December- January }\end{array}$ \\
\hline Season & Heparin & $\begin{array}{l}8 \text { males in summer } \\
8 \text { males in autumn }\end{array}$ & $\begin{array}{l}\text { June - July } \\
\text { August - September }\end{array}$ \\
\hline
\end{tabular}

\subsection{Blood Sampling}

Blood samples were collected by jugular vein puncture from each camel between $07 \mathrm{~h}$ and $08 \mathrm{~h}$ in a tubes with heparin and/or ethylene diamine tetra acetic acid-dipotassium (EDTA) (Table 1). Plasma was separated by centrifugation at $750 \mathrm{~g}$ for $15 \mathrm{~min}$ and eliminated, then red blood cells (RBCs) suspensions were prepared for the OF tests.

\subsection{Preparation of Erythrocytes Suspensions}

Erythrocytes were isolated by centrifugation of blood for $15 \mathrm{~min}$ at $1500 \mathrm{xg}$. The plasma and buffy coat were carefully removed using a micropipette. The cells pellet was washed three times with $310 \mathrm{mOsm}$ isotonic phosphate buffered saline (PBS) solution $\left(\mathrm{NaCl} 6 \mathrm{~g} / \mathrm{L}, \mathrm{HNa}_{2} \mathrm{PO}_{4} 3.20 \mathrm{~g} / \mathrm{L}, \mathrm{H}_{2} \mathrm{NaPO}_{4}, 2 \mathrm{H}_{2} \mathrm{O}\right.$ $0.33 \mathrm{~g} / \mathrm{L}, \mathrm{pH}=7.4$ ) and centrifuged at 1000xg for 10min. Finally, washed cells were suspended in an equal volume of isotonic PBS and were used to test the effects of anticoagulant, $\mathrm{T}^{\circ}$, storage time, sex, age and season. On erythrocytes suspensions prepared in the same way but washed with isotonic PBS at various $\mathrm{pH}$, the effect of $\mathrm{pH}$ on $\mathrm{H} \%$ was anlyzed. However, the RBCs suspensions prepared with a proportion of 5\% in isotonic PBS pH $7.4(\mathrm{v} / \mathrm{v})$, were used to test the effect of $\mathrm{H}_{2} \mathrm{O}_{2}$ on $\mathrm{H} \%$ and the protection of vitamins $\mathrm{C}$ and $\mathrm{E}$ against $\mathrm{H}_{2} \mathrm{O}_{2}$ induced $\mathrm{H} \%$. These constituted the RBCs suspensions, which were stored at $4^{\circ} \mathrm{C}$ for $24 \mathrm{~h}$ until further analysis [13]. Our tests were performed on the erythrocyte suspensions prepared from heparinized tubes.

\subsection{Effect of Anticoagulant}

To analyse the effect of the anticoagulant on erythrocytes hemolysis, $\mathrm{OF}$ was tested at $38^{\circ} \mathrm{C}$ on $\mathrm{RBCs}$ suspensions prepared from blood wich was collected in a tubes with heparin and EDTA.

\subsection{Effect of Storage Time}

The RBCs suspensions were stored at $4^{\circ} \mathrm{C}$ for 10 days and their OF was tested at each period of $24 \mathrm{~h}$ during storage. All tests were performed at $38^{\circ} \mathrm{C}$.

\subsection{Effect of Incubation Temperature}

The effect of temperature was analyzed on erythrocytes $\mathrm{OF}$ after incubation of RBCs suspensions in PBS isotonic solutions ( $\mathrm{pH} 7.4$ ) at $4^{\circ} \mathrm{C}, 18^{\circ} \mathrm{C}, 38^{\circ} \mathrm{C}, 42^{\circ} \mathrm{C}, 45^{\circ} \mathrm{C}$ and $50^{\circ} \mathrm{C}$ for $30 \mathrm{mn}$. Before the tests, all solutions and tubes were placed at the test temperature.

\subsection{Effect of $\mathbf{p H}$}

The effect of $\mathrm{pH}$ on erythrocytes $\mathrm{OF}$ was performed at $38^{\circ} \mathrm{C}$ on $\mathrm{RBCs}$ which were washed with PBS isotonic solutions with various $\mathrm{pH}(6.5 ; 7.4$ and 8.5) during preparation of erythrocyte suspensions. Buffering capacity is based on the couple dihydrogenophos-phate/hydrogenophosphate ( $\mathrm{pKa}=6.8$ ), which is also one of three major mechanisms for maintaining blood $\mathrm{pH}\left(\mathrm{HPO}_{4}{ }^{2-}+\mathrm{H}^{+}=\mathrm{H}_{2} \mathrm{PO}^{4-}\right)$. $\mathrm{PBS}$ solution at $\mathrm{pH} 7.4$ contained $\mathrm{NaCl}(6 \mathrm{~g} / \mathrm{L}$ or $102 \mathrm{mM})$, anhydrous $\mathrm{Na}_{2} \mathrm{HPO}_{4}(3.20 \mathrm{~g} / \mathrm{L}$ or $22 \mathrm{mM})$ and $\mathrm{NaH}_{2} \mathrm{PO}_{4}, 2 \mathrm{H}_{2} \mathrm{O}$ crystallized $(0.33 \mathrm{~g} / \mathrm{L}$ or $2 \mathrm{mM})$. At $\mathrm{pH} 6.5$ the solution contained $\mathrm{NaCl}(6 \mathrm{~g} / \mathrm{L}$ or $102 \mathrm{mM})$, anhydrous $\mathrm{Na}_{2} \mathrm{HPO}_{4}(30 \mathrm{mM})$ and $\mathrm{NaH}_{2} \mathrm{PO}_{4}, 2 \mathrm{H}_{2} \mathrm{O}$ crystallized $(14 \mathrm{mM})$. Whereas at $\mathrm{pH} 8.5$ the solution contained $\mathrm{NaCl}(6 \mathrm{~g} / \mathrm{L}$ or $102 \mathrm{mM})$, anhydrous $\mathrm{Na}_{2} \mathrm{HPO}_{4}(1 \mathrm{mM})$ and $\mathrm{NaH}_{2} \mathrm{PO}_{4}, 2 \mathrm{H}_{2} \mathrm{O}$ crystallized (43mM). Recall that the $\mathrm{pH}=\mathrm{pKa}+\log \left(\mathrm{NaH}_{2} \mathrm{PO}_{4} / \mathrm{Na}_{2} \mathrm{HPO}_{4}\right)$. 


\subsection{Age, Sex And Season}

To study the effect of age, sex and season on the OF of RBCs prepared from the heparinized blood, the test was performed at $38^{\circ} \mathrm{C}$ respectively on young and old camels, males and females camels and during summer and autumn seasons.

\subsection{Osmotic Fragility Test}

The OF of erythrocytes subjected to different conditions (anticoagulant, storage time, temperature and $\mathrm{pH})$ was determined by the procedure described by Oyewale [14] and Oladele et al. [9]. Briefly, sodium chloride $(\mathrm{NaCl})$ stock solution $(\mathrm{pH} \mathrm{7.4)}$ was prepared in volumes of $500 \mathrm{~mL}$ for each of the sample in concentration, ranging from $0.1 \%$ to $0.9 \%$. A set of 10 test tubes was used and each tube contained $10 \mathrm{~mL}$ of the corresponding $\mathrm{NaCl}$ concentration from the stock solution. The test tubes were then labelled with corresponding concentrations and arranged serially in a rack of 10 tubes. A $100 \mu 1$ aliquot of washed RBCs suspensions were added to each of the 10 test tubes in a set. The contents of the test tubes were gently mixed by inverting the test tubes five times and allowing them to stand at room temperature for $30 \mathrm{~min}$. Thereafter, the contents of the test tubes were centrifuged at $1500 \times \mathrm{g}$ for $15 \mathrm{~min}$. The supernatant was then transferred into a glass cup and measure data wave length of $540 \mathrm{~nm}$ using a spectrophotometer by reading the absorbance.

Hemolysis in each tube was expressed as a percentage, taking as $100 \%$ the maximum value of absorbance of distilled water. The percent hemolysis was calculated according to Faulkner and King [15] as follows:

Percent hemolysis $(\mathrm{H} \%)=($ Optical density of test/Optical density of distilled water)x 100 .

$\mathrm{H} \%$ curve was obtained by plotting percent hemolysis against the saline concentrations.

\subsection{Effect of Hydrogen Peroxide}

One hundred $\mu \mathrm{L}$ of RBCs suspensions (5\% in PBS pH 7.4) were mixed with $4.9 \mathrm{~mL}$ of $\mathrm{H}_{2} \mathrm{O}_{2}$ or distilled water or PBS solution. $\mathrm{H}_{2} \mathrm{O}_{2}$ was used at $0.5 \mathrm{mM} ; 2 \mathrm{mM}$ and $8 \mathrm{mM}$ and prepared with the PBS solution (Table 2).

Table2. Effect of Hydrogen Peroxide on Hemolysis

\begin{tabular}{|l|c|c|c|}
\hline RBCs (5\%) & PBS pH 7.4 & $\mathbf{H}_{\mathbf{2}} \mathbf{O}_{\mathbf{2}} \mathbf{0 . 5} ; \mathbf{2} ; \mathbf{8 m M}$ & $\mathbf{H}_{\mathbf{2}} \mathbf{0}$ \\
\hline $100 \mu \mathrm{l}$ & $4.9 \mathrm{ml}$ & 0 & 0 \\
\hline $100 \mu \mathrm{l}$ & 0 & $4.9 \mathrm{ml}$ & 0 \\
\hline $100 \mu \mathrm{l}$ & 0 & 0 & $4.9 \mathrm{ml}$ \\
\hline
\end{tabular}

RBCs: red blood cells suspensions, PBS: phosphate buffered saline.

All mixtures were incubated at $38^{\circ} \mathrm{C}$ for $60 \mathrm{mn}$. After centrifugation at $1500 \mathrm{rpm}$ for $10 \mathrm{~min}$, the absorbance of the supernatant was measured at $540 \mathrm{~nm}$ to determine the rate of induced $\mathrm{H}_{2} \mathrm{O}_{2}$ hemolysis as follows:

$\mathrm{H} \%=\left[\mathrm{DO}\left(\left(\mathrm{RBCs}+\mathrm{H}_{2} \mathrm{O}_{2}\right)-\mathrm{DO}(\mathrm{RBCs}+\mathrm{PBS})\right) / \mathrm{DO}\left(\mathrm{RBCs}+\mathrm{H}_{2} 0\right)\right] \times 100$.

Hemolysis in isotonic medium without $\mathrm{H}_{2} \mathrm{O}_{2}$ was:

$\left.\mathrm{H} \%=\mathrm{DO}(\mathrm{RBCs}+\mathrm{PBS})) / \mathrm{DO}\left(\mathrm{RBCs}+\mathrm{H}_{2} 0\right)\right] \times 100$.

\subsection{Protection of Vitamins $\mathrm{C}$ and $\mathrm{E}$ against $\mathrm{H} 202$ Induced Hemolysis}

Suspensions of RBCs (5\% in PBS pH 7.4) were incubated at $38^{\circ} \mathrm{C}$ for $30 \mathrm{~min}$, with vitamin $\mathrm{C}(20 ; 40$; $60 \mathrm{mM})$ or vitamin $\mathrm{E}(0.5 ; 1 ; 2 \mathrm{mM})$ or both (respectively $60 \mathrm{mM}$ and $2 \mathrm{mM})$. The vitamins solutions were prepared in PBS pH 7.4. To the mixture $\mathrm{H}_{2} \mathrm{O}_{2}(2 \mathrm{mM})$ was added. After incubation at $38^{\circ} \mathrm{C}$ for $60 \mathrm{~min}$, the mixture was centrifuged at $1500 \mathrm{rpm}$ for $10 \mathrm{~min}$ and the optical density of the supernatant was analyzed at $540 \mathrm{~nm}$ (Table 3).

Hemolysis in isotonic medium without $\mathrm{H}_{2} \mathrm{O}_{2}$ nor vitamins was:

$\left.\mathrm{H} \%=\mathrm{DO}(\mathrm{RBCs}+\mathrm{PBS})) / \mathrm{DO}\left(\mathrm{RBCs}+\mathrm{H}_{2} 0\right)\right] \times 100$,

$\mathrm{H}_{2} \mathrm{O}_{2}$ induced hemolysis in absence of vitamins was:

$\mathrm{H} \%=\left[\mathrm{DO}\left(\left(\mathrm{RBCs}+\mathrm{H}_{2} \mathrm{O}_{2}\right)-\mathrm{DO}(\mathrm{RBCs}+\mathrm{PBS})\right) / \mathrm{DO}\left(\mathrm{RBCs}+\mathrm{H}_{2} 0\right)\right] \times 100$

and $\mathrm{H}_{2} \mathrm{O}_{2}$ induced hemolysis of erythrocytes pre-treated with vitamins $\mathrm{C}$ and/or $\mathrm{E}$ was calculated as follows:

$\mathrm{H} \%=\left[\mathrm{DO}\left(\left(\mathrm{RBCs}+\mathrm{Vitamins}+\mathrm{H}_{2} \mathrm{O}_{2}\right)-\mathrm{DO}(\mathrm{RBCs}+\mathrm{PBS})\right) / \mathrm{DO}\left(\mathrm{RBCs}+\mathrm{H}_{2} 0\right)\right] \times 100$. 
LEKTIB Islah et al.

Table3. Protection of Erythrocytes by Vitamins $C$ and E against Hydrogen Peroxide Induced Hemolysis

\begin{tabular}{|c|c|c|c|c|c|c|c|}
\hline $\begin{array}{l}\text { RBCs } \\
(5 \%)\end{array}$ & $\begin{array}{c}\text { PBS } \\
\text { pH } 7.4\end{array}$ & $\begin{array}{c}\text { Vit C } \\
20 ; 40 ; 60 \mathrm{mM}\end{array}$ & $\begin{array}{c}\text { Vit E } \\
0.5 ; 1 ; 2 \mathrm{mM}\end{array}$ & $\begin{array}{c}\text { Vit C }(60 \mathrm{mM})+ \\
\text { Vit E }(2 \mathrm{mM})\end{array}$ & $\begin{array}{c}\text { PBS } \\
\text { pH } 7.4\end{array}$ & $\mathrm{H}_{2} \mathrm{O}$ & $\begin{array}{c}\mathrm{H}_{2} \mathrm{O}_{2} \\
(2 \mathrm{mM})\end{array}$ \\
\hline $100 \mu \mathrm{l}$ & $100 \mu 1$ & 0 & 0 & 0 & $4.8 \mathrm{ml}$ & 0 & 0 \\
\hline $100 \mu 1$ & $100 \mu 1$ & 0 & 0 & 0 & 0 & 0 & $4.8 \mathrm{ml}$ \\
\hline $100 \mu \mathrm{l}$ & $100 \mu \mathrm{l}$ & 0 & 0 & 0 & 0 & $4.8 \mathrm{ml}$ & 0 \\
\hline $100 \mu 1$ & 0 & $100 \mu 1$ & 0 & 0 & 0 & 0 & $4.8 \mathrm{ml}$ \\
\hline $100 \mu 1$ & 0 & 0 & $100 \mu \mathrm{l}$ & 0 & 0 & 0 & $4.8 \mathrm{ml}$ \\
\hline $100 \mu \mathrm{l}$ & 0 & 0 & 0 & $100 \mu 1+100 \mu 1$ & 0 & 0 & $4.7 \mathrm{ml}$ \\
\hline
\end{tabular}

RBCs: red blood cells suspensions, PBS: phosphate buffered saline.

\subsection{Statistical analysis}

The data were expressed in SI units and analyzed by the Mann-Whitney U test for comparison between situations or groups. All values were expressed as mean and standard error (SE), and $\mathrm{P}<0.05$ was seen as statistically significant.

\section{RESUlts}

\subsection{Effect of Anticoagulant}

As showed in Figure 1, the use of EDTA as an anticoagulant increased significantly (0.05) the OF of RBCs as compared with heparin. Thus, $0.4 \%, 0.3 \%$ and $0.2 \% \mathrm{NaCl}$ induced respectively $12 \pm 2 \%$, $21 \pm 2 \%$ and $98 \pm 4 \%$ hemolysis of erythrocytes isolated in EDTA, but induced respectively $6 \pm 2 \%$, $10 \pm 2 \%$ and $80 \pm 4 \%$ hemolysis of erythrocytes isolated in heparin (Fig. 1).

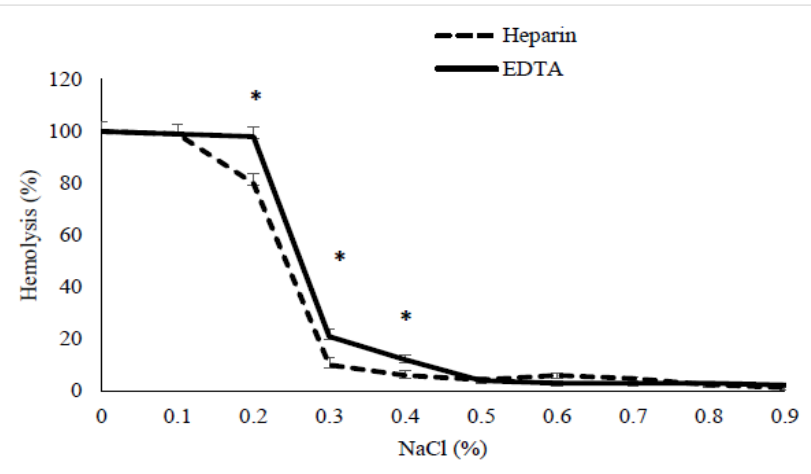

Figure1. The effect of anticoagulant on the osmotic fragility of erythrocytes prepared from blood collected in EDTA or heparin from dromedary camel (Mean $\pm S E, n=8$ males, $* P<0.05$, comparison between EDTA and heparin).

\subsection{Effect of Storage Time}

During the first five days of RBCs storage at $4^{\circ} \mathrm{C}$, the test of OF didn't show any significant variation of $\mathrm{H} \%$ in hypotonic $\mathrm{NaCl}$ solutions (Fig. 2). However, when compared to the first day, $\mathrm{H} \%$ measured at the 7th, 8th and 10th days of storage, showed a significant $(\mathrm{P}<0.05)$ shift of the curves to the right for $0.4 \%, 0.3 \%$ and $0.2 \% \mathrm{NaCl}$, indicating an decreased osmotic resistance of erythrocytes (Fig. 2). For example, in $0.3 \% \mathrm{NaCl}, \mathrm{H} \%$ at days $1,7,8$ and 10 was respectively $14 \pm 4 \%, 22 \pm 5 \%, 24 \pm 5 \%$ and $26 \pm 5 \%$ (Fig. 2).

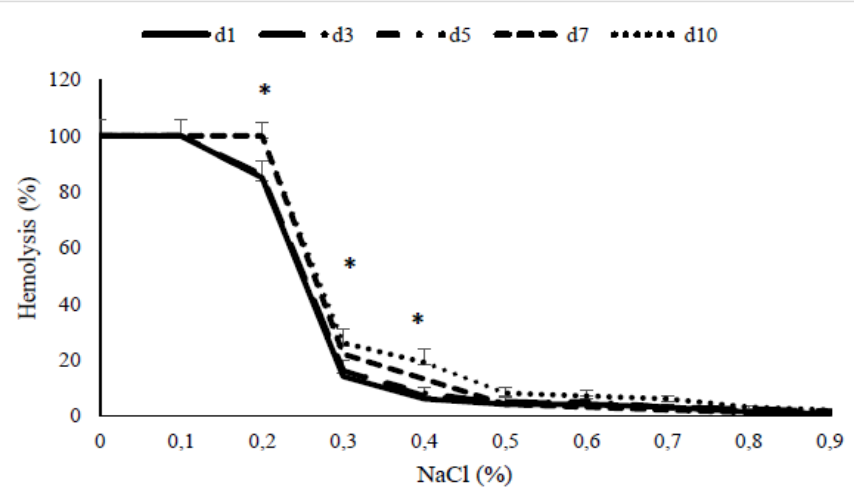

Figure2. The effect of storage time of erythrocytes at $4{ }^{\circ} \mathrm{C}$ on their osmotic fragility. The erythrocytes were isolated from blood collected in heparin from dromedary camels (Mean $\pm S E, n=7$ males, $* P<0.05$, comparison to day 1). 


\subsection{Effect of Temperature}

The OF curves of erythrocytes incubated in hypotonic salt solutions at $18^{\circ} \mathrm{C}, 40^{\circ} \mathrm{C}$ and $42^{\circ} \mathrm{C}$ didn't show any significant variation when compared to that analyzed at $37^{\circ} \mathrm{C}$. However, at $4^{\circ} \mathrm{C}$ and $50^{\circ} \mathrm{C}$, $\mathrm{H} \%$ becamed significantly $(\mathrm{P}<0.05)$ very higher than that observed at $37^{\circ} \mathrm{C}$ (Fig. 3$)$. Thus, in $0.3 \%$ $\mathrm{NaCl}$ at $4^{\circ} \mathrm{C}, 37^{\circ} \mathrm{C}$ and $50^{\circ} \mathrm{C}, \mathrm{H} \%$ was respectively $54 \pm 3,28 \pm 3$ and $58 \pm 4$ (Fig. 3).

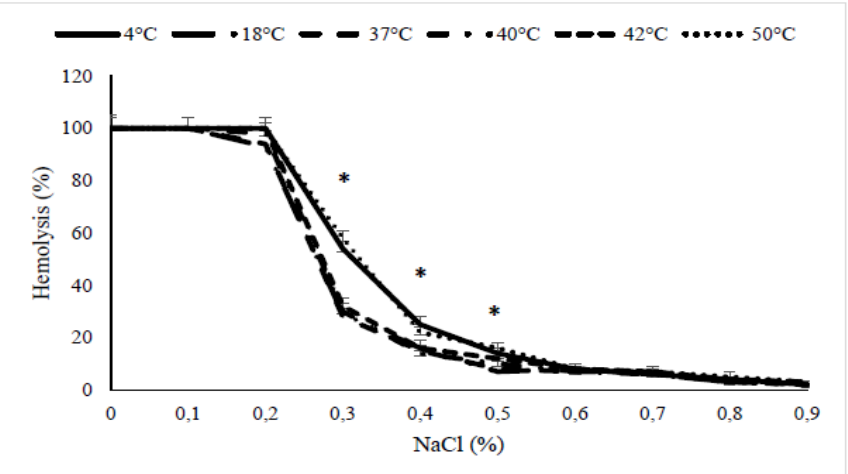

Figure3. The effect of temperature on osmotic fragility of erythrocytes isolated from blood collected in heparin from dromedary camels (Mean $\pm S E, n=7$ males, $* P<0.05$, comparison to $37^{\circ} \mathrm{C}$ ).

\subsection{Effect of $\mathbf{p H}$}

Comparatively to physiological $\mathrm{pH} 7.4, \mathrm{H} \%$ tested in $0.3 \%$ and $0.4 \% \mathrm{NaCl}$ showed a significant (0.05) variation with low value when $\mathrm{pH}=8.5$ and high value when $\mathrm{pH}=6.5$ (Fig. 4). For example, in $0.3 \% \mathrm{NaCl}, \mathrm{H} \%$ at $\mathrm{pH} 8.5,7.4$ and $6.5, \mathrm{H} \%$ was respectively $17 \pm 3 \%, 28 \pm 4 \%$ and $48 \pm 4 \%$ (Fig. 4).

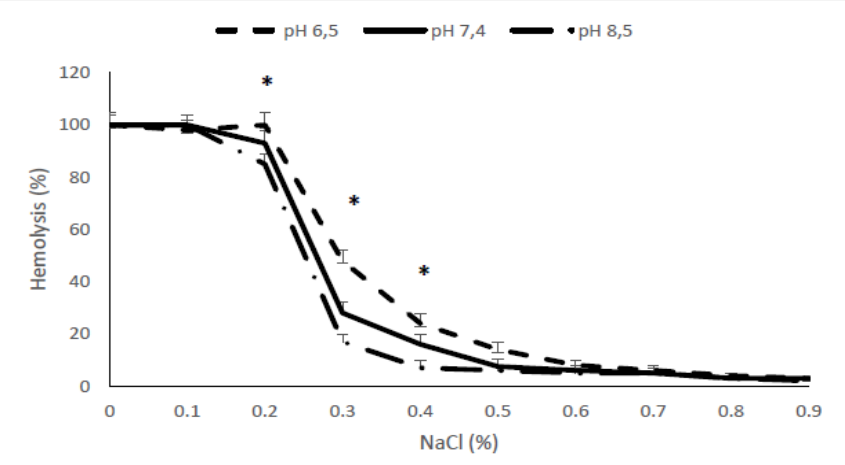

Figure4. The effect of $\mathrm{pH}$ on the osmotic fragility of erythrocytes isolated from blood collected in heparin from dromedary camel (Mean $\pm S E, n=7$ males, $* P<0.05$, comparison to $p H 7.4$ ).

\subsection{Effect of sex}

The results presented in Figure 5 showed a shift of the H\% curve of RBCs isolated from female camels to the left, indicating a significant $(\mathrm{P}<0.05)$ increased osmotic resistance of erythrocytes by comparison to male camels. Thus, in $0.4 \%, 0.3 \%$ and $0.2 \% \mathrm{NaCl}, \mathrm{H} \%$ in males was higher than that observed in females (respectively $14 \pm 3 \%$ vs $7 \pm 2 \%, 25 \pm 3 \%$ vs $11 \pm 2 \%$ and $98 \pm 4 \%$ vs $84 \pm 4 \%, P<0.05$ ) (Fig. 5).

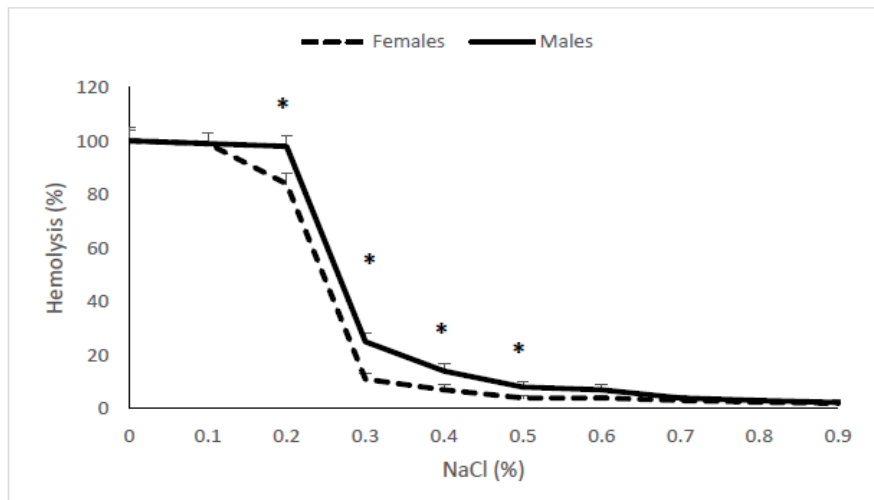

Figure5. The effect of sex on the osmotic fragility of erythrocytes isolated from blood collected in heparin from dromedary camel (Mean $\pm S E, n=6$ males and 6 females, $* P<0.05$, comparison between males and females). 


\subsection{Effect of Age}

Our results showed an increased osmotic resistance of erythrocytes in young male camels by comparison to that analyzed in old ones (Fig. 6). The hypotonic salt solutions $0.5,0.4 \%$ and $0.3 \%$ $\mathrm{NaCl}$ induced $\mathrm{H} \%$ significantly $(\mathrm{P}<0.05)$ higher in old camels than that observed in young ones (respectively $12 \pm 2 \%$ vs $7 \pm 1 \%, 17 \pm 3 \%$ vs $11 \pm 3 \%$ and $25 \pm 3 \%$ vs $16 \pm 3 \%$ ) (Fig. 6).

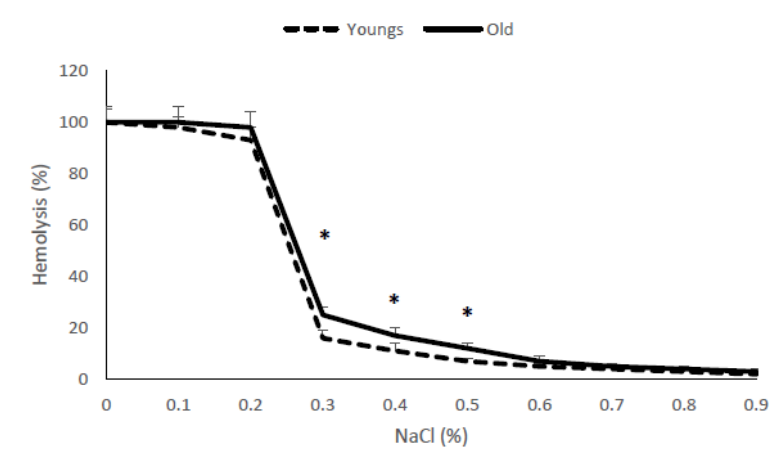

Figure6. The effect of age on the osmotic fragility of erythrocytes isolated from blood collected in heparin from male dromedary camel (Mean $\pm S E, n=7$ youngs and 7 olds, $* P<0.05$, comparison between youngs and olds).

\subsection{Effect of Season}

Erythrocytes of male camels, showed a significant $(\mathrm{P}<0.05)$ high osmotic resistance automn when compared to that analyzed during summer. Thus, $0.4 \%$ and $0.3 \% \mathrm{NaCl}$ solutions induced a high $\mathrm{H} \%$ during summer when compared to that measured during autumn (respectively $15 \pm 3 \%$ vs $8 \pm 2 \%$ and $27 \pm 3 \%$ vs $13 \pm 3 \%, \mathrm{P}<0.05$ ) (Fig. 7 ).

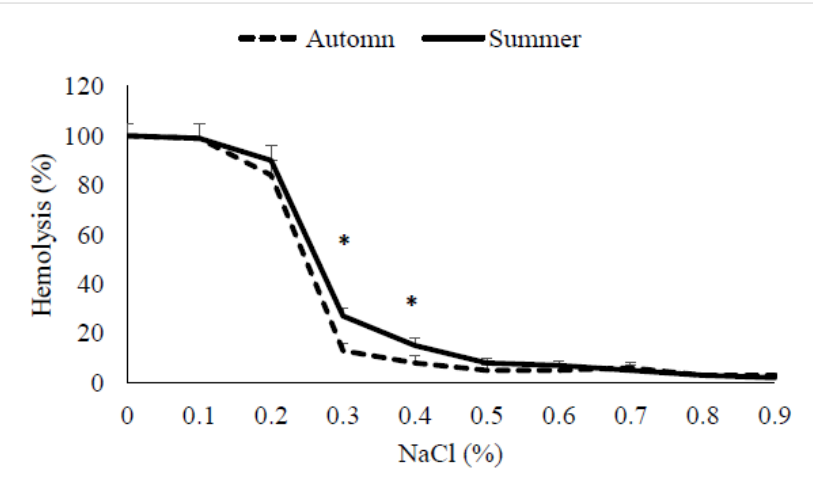

Figure7. The effect of season on the osmotic fragility of erythrocytes isolated from blood collected in heparin from male dromedary camel (Mean $\pm S E, n=8$ for each season, $* P<0.05$, comparison between summer and autumn).

\subsection{Effect of Hydrogen Peroxide}

After incubation with hydrogen peroxide $\mathrm{H} \%$ increased significantly when compared with that observed in distilled water. The $\mathrm{H}_{2} \mathrm{O}_{2}$ induced hemolysis was dose-dependant, thus, at $0,0.5,2$ and $8 \mathrm{mM} \mathrm{H}_{2} \mathrm{O}_{2}$ the $\mathrm{H} \%$ was respectively $18 \pm 1.6 \%, 46 \pm 8.6,62 \pm 7.2$ and $92 \pm 7.8$ (Fig. 8).

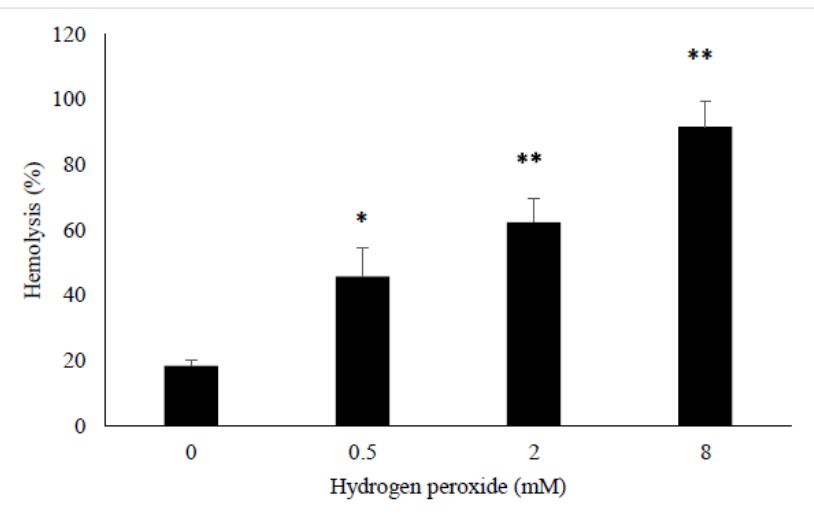

Figure8. The effect of hydrogen peroxide on the osmotic fragility of erythrocytes prepared from blood collected in heparin from dromedary camel (Mean $\pm S E, n=7$ males, $* P<0.05$, comparison to OmM hydrogen peroxide). 


\subsection{Protection of Vitamins $\mathrm{C}$ and $\mathrm{E}$ against $\mathrm{H} 202$ Induced Hemolysis}

The preincubation of RBCs with viamins $\mathrm{C}$ or $\mathrm{E}$ reduiced significantly $(\mathrm{P}<0.005)$ the $\mathrm{H}_{2} \mathrm{O}_{2}$ induced $\mathrm{H} \%$. The effects of these anti-oxidants were dose-dependant and becomed more significant $(\mathrm{P}<0.001)$ when the vitamins were associated (Fig. 9). $\mathrm{H}_{2} \mathrm{O}_{2}$ induced $\mathrm{H} \%$ was $5.7 \pm 0.6,7.2 \pm 0.6$ and $4.1 \pm 0.2$ after preincubation respectively with viamin $\mathrm{C}(60 \mathrm{mM})$, vitamin $\mathrm{E}(2 \mathrm{mM})$ and both $(60 \mathrm{mM}$ vit $\mathrm{C}+2 \mathrm{mM}$ vit E). However, $\mathrm{H}_{2} \mathrm{O}_{2}$ induced $\mathrm{H} \%$ without preincubation any vitamin was $72.4 \pm 6.3$ (Fig. 9).

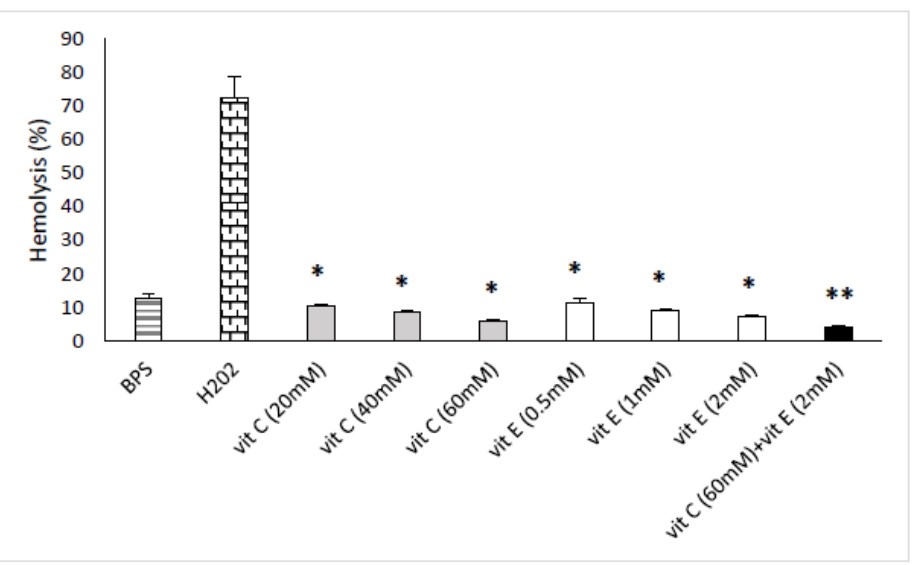

Figure9. The protector effect of vitamins $C$ and/or E against the hdrogen peroxide $(2 \mathrm{mM})$ induced hemolysis of erythrocytes isolated from blood collected in heparin from dromedary camel (Mean $\pm S E, n=7$ males, $* P<0.005$, $* * P<0.001$ comparison between presence and absence of vitamins).

\section{DisCUSSION}

The EOF test is easily influenced by several environmental and physiological factors. Therefore, we have undertaken an investigation whose aim was to determine osmotic fragility reference values in camel. Our results showed a significant shift of the hemolysis curves to the left in presence of. In addition, a significant shift of hemolysis curves to the right was observed in presence of heparin and vitamins $\mathrm{C}$ and $\mathrm{E}$, indicating a significant increased osmotic resistance of erythrocytes. These curves shifted to the right in presence of EDTA, storage time, heat, cold, acidity, sexe male, ageing and summer season, indicating a significant increased susceptibility to hypotonic lysis of RBCs. These differences were significant in $\mathrm{NaCl}$ concentrations of $0.3-0.4 \%$ where the changes in the extent of lysis as a consequence of changing $\mathrm{NaCl}$ concentrations were substantial.

The increased EOF obtained in our study when blood samples were collected in EDTA compared with heparin, was reported in man by several laboratories to result in an increased RBCs susceptibility to hypotonic lysis $[16,17,18]$. In hypotonic solution, vertebrate cells showed a rapid increase in cell volume followed by a slower regulatory volume decrease back to the original size [19]. This mechanism increases the efflux of intracellular osmolytes, thereby decreasing the driving force for water influx. $\mathrm{Ca}^{2+}$ ions may play an important role in this process for most cell types [19]. The depletion of extracellular $\mathrm{Ca}$ due to the chelation by EDTA may therefore be able to the decreased volume recovery of RBCs following hypotonic stress when compared to heparin. In addition, RBCs of animals bred on $\mathrm{Ca}^{2+}$-defficient diet showed an increased EOF [20].

In the work reported here, hemolysis of the RBC increases with storage time. Several reports on the effects of blood storage have shown significant alteration in RBC membrane integrity and flow properties and significant increase in the levels of free hemoglobin [21,22]. The presence of leukocytes in RBC suspension may also contribute significantly to the increase in hemolysis during storage [23,24]. During storage, leukocytes break down and release a number of chemicals and enzymes such as hydrogen peroxide and proteases. Proteases released by leukocytes during storage have been reported to cause RBC lysis during storage and are detrimental to their metabolism and viability [23,25]. Storage of red cells causes a progressive increase in hemolysis [26].

Hemolysis of camel's RBCs in hypotonic salt solutions increased much more when their incubation occured at very low $\left(4^{\circ} \mathrm{C}\right)$ or very high temperatures $\left(50^{\circ} \mathrm{C}\right)$. In fact, it was estabilished that the temperature greatly affects membrane deformability 50,56 and, therefore, the stability of the membrane during processing. So, human RBCs are damaged if warmed to a temperature of $40^{\circ} \mathrm{C} 54$. 
At temperatures at or less than $43^{\circ} \mathrm{C}$ and even up to $45-46^{\circ} \mathrm{C}$, it appears that blood heating is safe and causes hemolysis only in clinically negligible proportions [27]. According to Sharma et al. [28], thermal stress redistributes the body's nutrients including protein and energy at the expense of growth, reproduction, production and health of the animal. This enhances the occurrence of lipid peroxidation and induces changes in the fragility and antigenicity of the erythrocyte membrane [29].

The results showed that in camel, $\mathrm{RBC}$ hemolysis in salt hypotonic solutions, decreased when $\mathrm{pH}$ of incubation medium was 8.5 and increased when $\mathrm{pH}$ was 6.5 . Variations of environment $\mathrm{pH}$ involves all the main structural and functional RBCs links and may result in oxidative damage of cell membrane leading to hemolysis. The principal functions of RBCs are recognised to be the transport of oxygen and $\mathrm{CO}_{2}$, as well as the binding of acids and alkali, formed in tissues by metabolism, and their acidification can result in an elevation of potential endogenous cytotoxic metabolites [30]. Acidosis leads also to a release of metals with variable valency from metalloproteins, which participate in Fenton and Haber-Weiss reactions, stimulating $\mathrm{OH}^{*}$ and oxidant formation [31] that can result in oxidative damage to cell membranes and hemolysis [32].

Our results showed that EOF was very high in males camels than that observed in females. In fact, it has been established that erythrocytes of males are more susceptible to hemolysis than those of females in domestic fowl [33,34], cattle [35], WAD sheep [36], White Fulani cattle [37] and camel [38]. However, in contrast to these observations, other findings has enregistred a lower EOF in male compared to female. Such findings have been reported in African giant rats [39], dogs [40], turkeys [6] and goat [41]. On the other hand, in camel, the osmotic resistance increased significantly during the green season and decreased in winter [42].

The significant increase of EOF with age reported here, might be explained by metabolic alterations and a reduction of defense against OS. According to Walls et al., [43], young human cells were able to effectively protect themselves against thyroxine-peroxide induced hemolysis; however, old cells exhibited less protection. It should also be noted that the activity of G-6-PD is known to decrease with erythrocyte aging [44]. This decrease is associated with a decrease in glutathione concentration [45] and increased methemoglobin formation [46] in older cells. In addition, erythrocytes life span had been reported to decrease by $50 \%$ in older rats by comparison to younger ones [47], and their hemolysis had been suggested du to an increase of dolichol levels in their membranes [48].

The hydrogen peroxide induced hemolysis in camels, was attenuated by vitamins $\mathrm{C}$ and/or $\mathrm{E}$. The hydrogen peroxide increased metabolic activity in the RBC wich resulted in elevation in the production of reactive oxygen species (ROS). Due to the higher level of polyunsaturated fatty acids in erythrocyte cell membrane, the peroxidation of unsaturated chain of their membrane lipids increases the susceptibility of osmotic hemolysis [49,50]. It has been well established that the EOF test can be used to evaluate lipid peroxidation or oxidant stress (OS) in pig [10], rat [51], rabbit [49] and camel [11]. ROS are highly reactive non-specific molecules derived from the metabolism of oxygen including oxygen free radicals and other species such as hydrogen peroxide and singlet oxygen [52]. In rats submetted to OS induced by high altitudes stress, supplementation with vitamins $\mathrm{C}$ ans $\mathrm{E}$ reduced membrane instability and ROS, in terms of osmotic fragility and hemolysis, and increased the activity of glutathione peroxidase in the RBCs [53]. Furthermore, Vitamin E supplementation was showed able to protect human erythrocyte membranes from OS and improve membrane fluidity and reducing hemolysis [54]. In addition, in patients with advanced cirrhosis, low vitamin E plasma levels are associted with abnormal erythrocyte membrane lipids, structural alterations and chronic hemolysis [55].

Our results taken toghether indicate that EOF in camel may be influenced by EDTA, cold, heat, acidosis, sexe male, storage time, age and ROS. These factors induced erythrocytes destruction by damage to the their cell membrane and may disturb the results of other blood analyses such as measurements of various hematological and biochemical parameters in camel. Finally, vitamins $\mathrm{C}$ and/or E exhibited a good protection of camel RBCs against hemolysis.

\section{ACKNOWLEDGMENT}

The authors thank the President of urban municipalities of Casablanca and the Director and the responsible for veterinary of Casablanca slaughterhouse, to carry out this work. 


\section{REFERENCES}

[1] Jain S.K., McVie R. and Smith T., Vitamin E supplementation restores glutathione and malondialdehyde to normal concentrations in erythrocytes of type 1 diabetic children, Diabetes Care, 23(9),1389 (1983).

[2] Hanzawa K. and Watanabe S., Changes in osmotic fragility of erythrocytes during exercise in athletic horses, J. Equine Sci., 11(3), 51 (2000).

[3] Adenkola A.Y., Ayo J.O., Sackey A.K.B. and Adelaiye A.B., Erythrocyte osmotic fragility of pigs administered Ascorbic acid and transported by road for short-term duration during the harmattan season, Afr. J. Biotechnol. 9(2), 226 (2010).

[4] Minka N.S. and Ayo J.O., Physiological responses of Erythrocytes of goats to transportation and the modulatory role of ascorbic acid, J. Vet. Med. Sci., 72(7), 875 (2010).

[5] El Khasmi M., Chakir Y., Riad F., Safwate A., Tahri E.H., Farh M., El Abbadi N., Abouhafs R. and Faye B., Effects of Transportation Stress during the Hot-Dry Season on Some Haematological and Physiological Parameters in Moroccan Dromedary Camels (Camelus dromedarius), J. Life Sci. (USA), 7(1), 13 (2013).

[6] Azeez O.I., Olayemi F.O. and Olanrewaju J.R., Age and sex influences on the haematology and erythrocyte osmotic fragility of the Nigeria turkey, Res. J. Vet. Sci., 4, 43 (2011).

[7] Oladele S.B., Ogundipe S., Ayo J.O. and Esievo K.A.N., Effects of season and sex on packed cell volume, haemoglobin and total proteins indigenous pigeons in Zaria, Northern Nigeria, Vet. Arhiv., 71(5), 277 (2001).

[8] Oyewale J., Dzenda T., Yaqub L., Akanbi D., Ayo J.O., Owoyele O., Minka N. and Dare T., Alterations in the osmotic fragility of camel and donkey erythrocytes caused by temperature, $\mathrm{pH}$ and blood storage, Vet. Arhiv., 81(4), 459 (2011).

[9] Oladele S.B., Ayo J.O., Esievo K.A.N. and Ogundipe S.O., Seasonal and species variations in erythrocyte osmotic fragility of indigenous poultry species in Zaria, northern Guinea Savannah zone of Nigeria, Bull. Anim. Hlth. Prod. Afr., 51, 204 (2003).

[10] Adenkola A.Y. and Ayo J.O., Effect of road transportation on erythrocyte osmotic fragility of pigs administered ascorbic acid during the harmattan season in Zaria Nigeria, J. Cell. Anim. Biol., 3(1), 004 (2009).

[11] El Khasmi M., Chakir Y., Bargaâ R., Barka K., Lektib I., El Abbadi N., Belhouari A. and Faye B., Impact of transport distance on stress biomarkers levels in dromedary camel (Camelus dromedarius), Emir. J. Food Agric. 27(6), 507 (2015).

[12] Sowemimo-Coker S.O., Red Blood Cell Hemolysis During Processing, Transfus. Med. Rev., 16(1), 46 (2002).

[13] Dodge J.T., Mitchell, C. and Hanahan D.J., The preparation and chemical characteristics of hemoglobin-free ghosts of human erythrocytes, Arch. Biochem. Biophys, 100, 119 (1963).

[14] Oyewale J.O., Effects of storage of blood on the osmotic fragility of mammalian erythrocyte, J. Veter. Med. A, 40, 258 (1993).

[15] Faulkner W.R. and King J.W., Manual of clinical laboratory procedures. Clevel and Ohio, 1970, p354.

[16] Godal H.C., Nyvold N. and Rustad A., The osmotic fragility of red blood cells: a re-evaluation of technical conditions, Scan-dinavian J. Haematol., 23(1), 55 (1979).

[17] Kafka M. and Yermiahu T., The effect of EDTA as anticoagulant on the osmotic fragility of erythrocytes, Clin. Lab. Haem., 20(4), 213 (1998).

[18] De Caro L., Ghizzi A., Bensi L., Berti P. and Minelli R. Activity of natural fatty acids on erythrocyte osmotic resistance, Bol-letino-Societa Italiana Biologie Sperimentale, 67, 861 (1991).

[19] Pierce S.K. and Politis A.D., $\mathrm{Ca}^{2+-}$ activated cell volume recovery mechanisms. Annu. Rev. Physiol., 52, 27 (1990).

[20] Roth H.P. and Kirchgessner M., The effect of dietary fats on the hemolysis resistance of the erythrocyte membrane during alimentary zinc and calcium deficiency in rats, Z Ernahrungswiss, 30, 98 (1991). 
[21] Arun P., Padmakumaran Nair K.G., Manojkumar V., Deepadevi K.V., Lakshmi L.R. and Kurup P.A., Decreased hemolysis and lipid peroxidation in blood during storage in the presence of nicotinic acid, Vox Sang, 76(4), 220 (1999).

[22] Weisbach V., Wanke C., Zingsem J., Zimmermann R. and Eckstein R., Cytoklne generation in whole blood, leukocyte-depleted and temporarily warmed red blood cell concentrates, Vox Sang, 76(2), 100 (1999).

[23] Humbert J.R., Fermin C.D. and Winsor E.L., Early damage to granulocytes during storage, Semin. Hematol., 28(3 Suppl 5), 10 (1991).

[24] Heaton W.A., Holmes S., Smith K., Brecher M.E., Pineda A., AuBuchon J.P. and Nelson E., Effects of 3-5 $\log 10$ pre-storage leucocyte depletion on red cell storage and metabolism, Br. J. Haematol., 87(2), 363 (1994).

[25] Greenwalt T.J., Zehner Sostok C. and Dumaswala U.J., Studies in red blood cell preservation. 1. Effect of the other formed elements, Vox Sang, 58(2), 85 (1990).

[26] Makroo R.N., Vimarsh Raina, Aakanksha Bhatia, Richa Gupta, Abdul Majid, Uday Kumar Thakur and Rosamma N.L., Evaluation of red cell hemolysis in packed red cells during processing and storage, Apollo Medicine, 7(1), (2010).

[27] Poder T.G., Nonkani W.G. and Leponkouo E.T., Blood Warming and Hemolysis: A Systematic ReviewWith Meta-Analysis, Transfus. Med. Rev., 29(3), 172 (2015).

[28] Sharma S., Ramesh K., Hyder I., Uniyal S., Yadav V.P., Panda R.P., Maurya V.P., Singh G., Kumar P., Mitra A. and Sarkar M., Effect of melatonin administration on thyroid hormones, cortisol and expression profile of heat shock proteins in goats (Capra hircus) exposed to heat stress, Small Rum. Res., 112(1), 216 (2013).

[29] Pfatfeort C., Meiselman H.J. and Hochstein P., The effect of malondialdehyde on erythrocytes deformability, Blood, 59(1), 12 (1982).

[30] Ilani A. and Granoth R., The pH dependence of the hemolytic potency of bile salts, Biochim. Biophys. Acta, 1027(2), 199 (1990).

[31] Hermes-Lima M. and Zenteno-Savin T., Animal response to drastic changes in oxygen availability and physiological oxidative stress, Comp. Biochem. Physiol. C Toxicol. Pharmacol., 133(4), 537 (2002).

[32] Ivanov I.T., Low pH-induced hemolysis of erythrocytes is related to the entry of the acid into cytosole and oxidative stress on cellular membranes, Biochim. Biophys. Acta, 1415(2), 346 (1999).

[33] March B.E., Coates V. and Biely J., The effects of oestrogen and androgen on osmotic fragility and fatty acid composition of erythrocytes in chicken, Can. J. Physiol. Pharmacol., 44(3), 379 (1966).

[34] Oyewale J.O. and Durotoye L.A., Osmotic fragility of erythrocytes of two breeds of domestic fowl in the warm humid tropics, Laboratory Animal, 22, 250 (1988).

[35] 35. Olayemi F.O., The effect of sex on the erythrocyte osmotic fragility of the Nigerian White Fulani and Ndama breeds of cattle, Trop. Veter., 25, 106 (2007).

[36] Durotoye L.A., Effect of sex, pregnancy and lactation on the osmotic fragility of erythrocyte of the West African Dwarf sheep, Bull. Anim. Health Prod. in Africa, 35(1), 29 (1987).

[37] Olayemi F.O., Erythrocyte osmotic fragility, haematological and plasma biochemical parameters of the Nigerian White Fulani cattle, Bull. Anim. Hlth. Prod. Afr., 52(3), 208 (2004).

[38] Amin A. S., Abdoun K.A. and Abdelatif A.M., Erythrocyte osmotic fragility curve of male and female camels (Camelus dromedarius), Conference Proceedings, International Society of Camelid Research and Development, Pp. 288-289, (2012).

[39] Oyewale J.O., Olayemi F.O. and Oke O.A., Haematology of the wild adult African giant rat (Cricetomys gambianus, Waterhouse), Vet. Arhiv., 68, 91 (1998).

[40] Olayemi F.O., Azeez I.O., Ogunyemi A. and Igheghan F.O., Study on the erythrocyte values of the Nigerian breed of dog, Folia Veterinaria 53(2), 65 (2009).

[41] Habibu B., Yaqub L.S., Ahmed I.A., Kawu M.U., Buhari H.U., Tauheed M. and Isa H.I., Erythrocyte Osmotic Fragility and Haematologic Parameters of Three Breeds of 9-Week-Old Broiler Chickens, Int. J. Poultry Sci. 12(5), 277 (2013). 
[42] Amin A.S., Abdoun K.A. and Abdelatif A.M., Seasonal variation in blood constituents of onehumped camel (Camelus dromedarius), Pakistan J. Biol. Sci., 10(8), 1250 (2007).

[43] Walls R., Sree Kumar K. and Hochstein P., Aging of Human Erythrocytes, Differential Sensitivity of Young and Old Erythrocytes to Hemolysis Induced by Peroxide in the Presence of Thyroxine, Arch. Biochem. Biophys., 174(2), 463 (1976).

[44] Ramot B., Brok-Simoni R. and Ben-Bassat I., Glucose 6-phosphate dehydrogenase, hexokinase activities and ATP levels as a function of cell density in thalassemia and iron deficiency anemia, Ann. N.Y. Acad. Sci., 165(1), 400 (1969).

[45] Rigas D.A. and Koler R.D., Decreased erythrocyte survival in hemoglobin H disease as a result of the abnormal properties of hemoglobin H: the benefit of splenectomy, Blood, 18, 1 (1961).

[46] Keitt A.S., Smith T.W. and Jandl J.H., Red cell "pseudmosaicism» in congenital methemoglobinemia, New Eng. J. Med., 275, 397 (1966).

[47] Glass G.A., Gershon H. and Gershon D., The effects of donor and cell age on several characteristics of rat erythrocytes, Exp. Hematol., 11(10), 987 (1983).

[48] Dolfi C., Cavallini G., Donati A., Gori A., Innocenti Z., Maccheroni B., Paradiso M., Pollera C. and Bergamini E., Accumulo senile del dolicolo : un biomarcatore di invecchiamento?, Giornale Gerontol., 47, 275 (1999).

[49] 49. Brzezinska-Slebodzinska E., Erythrocyte osmotic fragility test as the measure of defense against free radicals in rabbits of different ages, Acta Vet. Hung., 49, 413 (2001).

[50] Brunet-Rossinni A.K., Reduced free-radical production and extreme longevity in the little brown bat (Myotis lucifugus) versus two non-flying mammals, Mech. Ageing Dev., 125(1), 11 (2004).

[51] Abdul Wahab A., Mabrouk M.A., Ayo J.O., Ambali S.F., Shittu M., Yahaya A.A. and Oluwatobi S.E., Effects of co-administration of antioxidants on erythrocyte osmotic fragility of wistar rats during the hot-dry season, Eur. J. Sci. Res. 46(1), 073 (2010).

[52] Scherz-Shouval R. and Elazar Z., Regulation of autophagy by ROS: physiology and pathology, Trends Biochem. Sci., 36(1), 30 (2011).

[53] Vani R., Reddy C.S. and Asha Devi S., Oxidative stress in erythrocytes: a study on the effect of antioxidant mixtures during intermittent exposures to high altitude, Int. J. Biometeorol., 54(5), 553 (2010).

[54] Sun Y., Ma A., Li Y., Han X., Wang Q. and Liang H., Vitamin E supplementation protects erythrocyte membranes from oxidative stress in healthy Chinese middle-aged and elderly people, Nutr Res. 32(5), 328 (2012).

[55] Restellini S., Alaei M., Matthes T., Kherad O., Moschetta A. and Spahr L. Effect of hydrosoluble vitamin $\mathrm{E}$ on erythrocyte membrane lipid composition in patients with advanced cirrhosis: An open-label pilot trial, Hepatol. Res., 45(8), 890 (2015). 